\title{
An Exploration of COVID-19 and Its Consideration as a Black Swan for the Construction Industry in Switzerland
}

\author{
Adrian August Wildenauer, University of Economics and Business, Prague, Czech Republic \\ D https://orcid.org/0000-0003-4414-9352 \\ Josef Basl, University of Economics and Business, Prague, Czech Republic
}

\begin{abstract}
COVID-19 and its devastating yet unforeseeable effects affect the entire global economy value chain. Effects will be long-lasting and interfere with the way construction worked so far. Losses in the industry are expected to run into billions; spending on new buildings are predicted to decrease sharply and on a global long-term. COVID-19 is, depending on the viewpoint, either a "White Swan," which is a probable event, causing massive consequences, or a "Black Swan," which is additionally not foreseeable. The European Green Deal presented by the European Commission could serve as a new Marshall Plan to enable the long-awaited digitisation of the construction industry. A whole industry sector is called upon to undergo a digital empowerment within a very short period, for which other branches of industry have had years or even decades. Can this crisis serve as a spark for eventually starting the digitalisation of the construction industry?
\end{abstract}

\section{KEYWORDS}

BIM, Black Swan, Built Environment, Construction Industry, COVID-19, Digitalisation, New Green Deal, Switzerland, White Swan

\section{INTRODUCTION}

The construction industry is not known for its end-to-end digital maturity, confirmed by many researchers, pointing especially to the low spread of digital working methods (compare Grilo \& Jardim-Goncalves, 2010; Gehring et al., 2017) with low interoperability of different file and exchange formats and therefore between different stakeholders (da Silva Serapião Leal et al., 2019; Gallaher et al., 2004; Nývlt \& Novotný, 2019; Wildenauer, 2020b). Moreover, the complexity of construction projects is increasing on- and offsite for the planning, execution and operation (Bani Feriel et al., 2018), with mostly a non-existing data governance (Alreshidi et al., 2017) with a project and people based knowledge management approach (Eken et al., 2015). This non-continuous digital data flow for all phases from planning to maintenance is causing up to $45 \%$ of the invested sum being misinvested (Barber, 2005; Barbosa et al., 2017; Flyvbjerg, 2007; Teicholz, 2013). This results in the 
growing need for transparency and disclosure to stakeholders and public authorities in particular as contracting authority (Fabig \& Haasper, 2016).

To put it mildly, the construction industry has - whether it is unjustified or legitimate - a reputation for digital ignorance (Bertschek et al., 2019). The digital transformation of the industry has just commenced in many sub-sectors there, but in part selectively and not consistently. The initially described problems do not occur by themselves but are interdependent. Taken this into account, one of the main challenges is to ensure a seamless digital data flow which would save substantial resources in the built environment process (Olsson et al., 2019), which shall lead to significant cost savings in all life cycle phases of a building (Thanthirige, 2020). The impacts triggered by COVID-19 are fuelling these consequences.

\section{OVERALL ECONOMIC IMPACT OF COVID-19}

The figures are impossible to gauge; for the Swiss economy alone, it is assumed that there will be a loss in net value added in the amount of app. CHF 33 billion for the year 2020, which is approximately Euro 30 billion (Schläper, 2020). This represents about $6 \%$ of Switzerland's Gross Domestic Product (CIA, 2021). An amount of almost CHF 1.9 billion in rental income will be lost this year, or the mutual tenancy agreements and the application of tenancy law is restricted due to legal crisis packages (BWO, 2020). Almost 140,000 working years of economic output has not been performed since 17.03.2020, the official day of the first Swiss lockdown (Schläper, 2020), with no end in sight and no comparable numbers for the second lockdown starting 18.01.2021. The general figures for the international community are not differing in large numbers (CCSA, 2020). The interim economic outlook forecasts are expecting a decline of at least $0.5 \%$ compared to the latest figures of 2019 (OECD, 2020).

The current crisis will have a significant impact (Altman, 2020), with almost halving the worldwide foreign direct investments in a pessimistic scenario and reducing international travel on a third of the original amount within a very short time frame. The World Trade Organization (WTO) predicts that global merchandise trade will decline between $13 \%$ and $32 \%$ in 2020, depending on the duration and depth of trade restrictions caused by the virus. The figures were published already in April 2020 and will be subject to an adjustment. Due to the complex interrelationships through linked value chains, the WTO assumes that these declines will be much higher with the biggest employment decline since 1945 (CCSA, 2020; WTO, 2020). Basically, it must be questioned whether the economy and the associated supply chains are so robust when a short-term interruption in supply chains leads to such dramatic long-term effects.

Moreover, statistics show that the gross domestic product for the United States have dropped by approximately $30 \%$ within weeks (Azoulay \& Jones, 2020). Yet, this situation is not comparable with a total collapse: "an economy in which $50 \%$ of the economy is fully shut down, as in a pandemic, is not the same as one in which all economic activity collapses by $50 \%$, as in a depression. In a pandemic, a sector's relationship to the rest of the economy determines the outcome" (Marin, 2020). The pandemic clearly shows the interdependency between different sectors and their interconnected value chains. However, compared to the losses, the spending on Research and Development necessary to fight this pandemic would have been a fractional amount (Azoulay \& Jones, 2020). Critics claim that there was no scenario planning in the United States (McNutt, 2020). However, there was a pandemic plan in Switzerland already installed in 2004 with the latest update in 2017 (Mathys, 2018), which unfortunately was not put into action in the federal system by cantonal governments due to trivialisation and misjudgements (Zeltner, 2018; Zeyer, 2020). This has led to intensive cost increases in overcoming the crisis.

These economic impacts have led to very drastic measures of governments (Kuckertz et al., 2020), which were often not harmonised neither on an regional (Bundespresseamt, 2020), nor national (France24, 2020) nor European (Brehon, 2020) nor on an worldwide level (compare the 
extensive Data evaluation of the United Nations (CCSA, 2020)). If not harmonised, the "utility can be up to $69 \%$ lower when states fail to coordinate in the presence of spillover" (Holtz et al., 2020). Comparing the measures taken in Europe it is obvious that there is a country-by-country procedure, not an overall plan (Artenie, 2020). Hence, there are different national approaches from the European Development Finance Institutions (European International Contractors, 2020). Switzerland alone spent over CHF 72 billion within three months (Farman, 2020). Moreover, not every member country of the EU has the same stamina and financial robustness to recover from a crisis, as investigated in a recent study about the resilience of EU member states concerning the 2007-2012 happening economical financial crisis. It showed only a few countries are resilient against a crisis (Alessi et al., 2020). A similar starting position is found in the first investigations regarding COVID-19. Overall, the response rating of Europe in terms of pandemic control and resilience, as of 08.06.2020, is the highest of all global regions. However, here are significant differences in Europe, too: the range extends from Switzerland in first place, followed by Germany in second place, the Czech Republic in 43 and Belgium in 78. This disunity leads to extremely high follow-up costs for each individual country, leading to consequential costs that cannot yet be quantified and may also result in economic repercussions not only for the individual country.

\section{State of Construction}

Today's construction industry is usually heavily dependent on cross-border supply of building materials and prefabricated parts (Fredenlund et al., 2020), as it is still an industry depending on craftsmanship (Rickers \& Ammermann, 2016) and the extensive use of material - mostly on a single use basis (Rau \& Oberhuber, 2018). Moreover, it is still connected with the classic Taylorism (Haakestadt \& Friberg, 2017), defining tasks in a manufacturing environment in a precise way, in terms of a defined and agreed performance output and specific time to perform a given task, e.g. erecting an asset (Asyali \& Bastug, 2014) - all based on the human interaction with physical building materials. To put simply, construction projects are usually manufactured as unique, highly individual, handcrafted items on site at the customer's premises. This causes a chain reaction. The fluctuation in construction companies is one of the highest, especially in crisis (compare the extensive work of Balcerzyk et al., 2019) and at the same time highly dependent on personnel - empirical knowledge on the construction site is not to be replaced without difficulty. The resulting effects lead to low margins and high risks, low customer satisfaction and the time and budget overruns already mentioned. This could be one of the reasons why the rate of return is one of the lowest in all comparable sectors and expenditure, compared with gross value added, is highest (Wolstenholme, 2009). Several interdependent questions arise as why the construction industry has not adopted, or slowed down to adopt, the technological elaborations of recent decades.

The construction industry is one of the largest industry in global economy (including real estate, infrastructure and industrial structures), forms one of the most indolent sectors in terms of digital transformation (Barbosa et al., 2017; Ribeirinho et al., 2020), mostly associated with negative public relations regarding delays, budget overruns and poor planning and execution quality (Barber, 2005; Egan, 1998; Flyvbjerg et al., 2002, 2003; Teicholz, 2001). These are not new developments, but a manifest continuation of unsatisfactory aspects of classic project management - deadlines, costs and quality. Only cost-effective, short-term measures were implemented, and this was often done only grudgingly and not to the necessary extent.

Over twenty years ago, several attempts were taken in the United Kingdom to overcome this burden (Egan, 1998; Latham, 1994; Wolstenholme, 2009) and to make the industry more robust and crisis-prone, with the first reports already in the mid-1940's. Other countries followed with a certain time lag - although the challenges are almost unanimous, the reactions and measures taken are to some extent very heterogeneous. It is stated, that "in practice, [changes in behaviour] requires a willingness on the part of contracting authorities, planners and building contractors to embark on new paths" (Püstow et al., 2018). 
Hitherto, construction industry is not very well known for their overall digitalisation efforts compared to other industries (Wildenauer, 2020a). The industry was reluctant to change (Egan, 1998; Gardiner, 2014; Latham, 1994; Teicholz, 2001) and is still continuing to show passive resistance to any distinct, digital or data-based development of current working methods. (Schmidt-Gayk, 2003). On a transnational level, the situation is even more complicated, leading to significant overspendings, lacking in communications and exceeding deadlines, in average 11 years in large-scale projects (European Court of Auditors, 2020). Despite all these disturbing factors, the construction industry seems to be passive and waiting to see whether digitisation is really rewarding (Wildenauer, 2020a). The agricultural sector (Barbosa et al., 2017), which is considered even a "non-digital" business, is taking advantage of the opportunities offered by digitization and is very quickly preparing for an overdue digital transformation through automation and a consistent orientation (Metzger, 2020). Extensive expert reports provide a "digital poverty testimony" to the building industry's ability to digitise (Bertschek et al., 2019). There is an exception to the rule with the results rarely taken seriously. It is argued that due to this evocating reports the collaboration improved but is not at an comparable level with other industries (Gardiner, 2014). Why is the industry on the one hand partly innovative in the technical and technological development of individual areas, but on the other hand resistant to the use of these technological developments that further develop the industry?

The answer to this question can only be partial and not exhaustive, as there is not just one reason in the complexity of construction. One explanation may be that no digital methods were previously required for the physical construction and completion of buildings; much was based on the experience of those involved in the construction. Construction is usually project-based and characterised by phases that cover long periods of time (Klinger \& Susong, 2006). Companies are usually partially involved, commissioned for a specific supply respectively service contract or for a temporary work deployment in these phases of a project (Yang \& Wei, 2010). The phases are either overlapping or sharply separated in terms of processes, participants and delivery results (CIOB, 2014). In the case of overlapping phases, inconsistencies, extra work and unclear responsibilities are often the norm. In separated phases, these are creating interfaces at every transition from one phase to the next (for example the preliminary design to detailed design), as those involved in one phase or another are no longer involved or no longer are contractually bound. Winch, 2012 suggests here the establishment of quality reviews after each phase. However, these are usually not conducted with due care - a sufficient number of large, complex and unsuccessful building projects can be brought into consideration here. These projects are considered to be a ,white elephant“ - prestigious to build but expensive in construction and maintenance (Cox et al., 2006).

Additionally, it was simply not necessary to use bits and bytes to represent the buildings created with mortar and stones. Building owners did not ask for the implementation of digital methods for their projects or were not interested in the further use of data created by companies (Lindblad \& Vass, 2015). Most of the time building owners were not able to use the possibly received data further or to use them for their purposes (Vozzola et al., 2009). Furthermore, it was seldom possible to use this data to gain profitable insights in the facility management phase following the construction phase, as there is still no consistent data format for all aspects of a construction project from the project idea to demolition (Bellido-Montesinos et al., 2019).

Moreover, most real estate companies pointing out that even though the use of BIM is accepted used in planning and construction of the building, the use in the operational phase is yet marginal (Árnandóttir, 2019; Gao \& Pishdad-Bozorgi, 2019), although it is still considered one of the most important topics in the lifecycle of a building (Kam, 2016; Nicał \& Wodyński, 2016; Sacks et al., 2018). The loss, incorrect transmission or poor interpretation of ambiguous data during the transition from the design and construction phase to the operational phase of built assets is still a major problem leading to individual specifications and agreements of clients (Lindblad \& Vass, 2015; Munir et al., 2020; Wildenauer, 2018b) and therefore a low spread of digital methods. Zheng et al., 2017 point out that most clients appoint construction companies ostensible to digital methods. In most cases, building 
owners must rely on references and the voluntary information provided by building contractors in a pre-project phase, the tendering for projects.

\section{Impact of COVID-19 on Construction in Switzerland}

Although Switzerland is not a member of the European Union but of the European Economic Area (EEA), Switzerland and Germany are comparable in many aspects, starting with their geographical location, a high overall economic output (Baublatt, 2020), a similar level of education with a close partnership concerning research and development (WBF, 2019) and a comparable contribution of the construction industry to the gross value added of the respective country. Moreover, both countries are heavily interdependent (Kohler, 2019). For this reason, studies and analyses from these two countries and on a European basis are used in this document.

In spring 2020 it was still assumed that the construction industry would experience stable growth of around 0.5 to $0.9 \%$ (Feld et al., 2020), the forecasts changed with COVID-19 - significantly (Dahm $\&$ Fischer, 2020). For the second quarter, the Construction Index Switzerland (Bauindex Schweiz) lost almost 7\% compared with 2019 and predicts not only a reduction of the gross domestic product of at least $3.5 \%$ for 2020 but also a deep recession for the next few years with similar predictions for Germany (Walert \& Maniera, 2020; WüestPartner, 2020). The business sentiment in construction dropped strongly in May 2020 from 34 points to just 3.78 (seasonally adjusted), resulting in a short term work application rate of approximately 50\% (Funk, 2020). Construction companies in the canton of Ticino in Switzerland, a canton bordering on Italy, announce declines in orders of almost $30 \%$ within a very short time; the cantons bordering to France stated drops of almost $15 \%$. The same figures apply to construction activities (Schweizerischer Baumeisterverband, 2020). Interestingly enough, the number of employment ads, a leading indicator of construction activities plummeted heavily by $27 \%$ in the second quarter of 2020 (sda, 2020). Almost 70 percent of the companies are already reporting a slowed decline in sales, some of them severe (Knitterscheidt, 2020). Several traders of building materials have closed their branches and are not supplying construction sites (Price, 2020), resulting in lower production and lower profit margins of large suppliers (Buchenau $\&$ Hofmann, 2020). Based on current developments, the ratings of the first open-end real estate funds in Germany have already broadly been reduced. These funds manage over Euro 100 billion in real estate investments, almost two thirds consisting of office buildings (Knorr et al., 2020). Not only in Germany, but also in Switzerland, a rather flat recovery path for the economy is predicted, resembling a flat V (Credit Suisse AG, 2020a). Despite all these facts, the case of "survivorship bias" should not be forgotten, which is an exaggeration or cognitive distortion. Here, the probabilities of success are systematically overestimated, since successful persons or conditions are more visible than unsuccessful ones (Taleb, 2007; Wirtz, 2019). This is the case when considering these figures, as they are primarily voluntary reports from companies that continue to exist; insolvent companies are not included. The Swiss construction sector performed well but at a low level in terms of profitability (Funk, 2020; Jank et al., 24.02.020).

\section{Effects on Digitisation Capabilities of Construction}

Considering the possible areas of digitisation in the construction industry, a strong gradient in the digitisation capacity of the individual sub-sectors of the industry emerges quickly (Herr et al., 2020). This commences with a very high digitisation capacity in the preplanning phase concerning financial issues and valuations and is reduced to the end of the life cycle phase of demolition/dismantling, where experience shows that little can be digitised. In this respect, the field of digitization capability in the construction industry is also widely spread. Surprisingly, the assumptions of "Industry 4.0" and their effects on the world of work, which have so far been very euphemistic, with regard to robotization, predictive maintenance of plants, three-dimensional printing in-situ (such as a construction site), modularization and the associated flexibilization, have not yet materialized. This, despite the fact that the topic has been shaped since 2011 (Mahlke \& Buitenhuis, 2019). However, experts point out 
that this is a paradigm shift that has had a strong impact on the industry, such as Computer Integrated Manufacturing (including Computer Aided Design) and Lean Production. This is worrying, especially if one considers that these are concrete and complete transformation plans and not the description of already existing developments on a large scale (Mahlke \& Buitenhuis, 2019). Industry 4.0 focuses on strong process optimization, connectivity of production facilities, smart and integrated solutions (Kagermann et al., 2013) and standardised components, processes and appliances (Obermaier, 2019). Enterprises struggle to apply the [digital] transformation, notably, when integrating digital solutions their core business and identify new governance models (Bordeleau \& Felden, 2019). A recently conducted survey showed that two-thirds of the respondents believe that COVID-19 will lead to an acceleration of the [digital] transformation [of the construction industry] (Ribeirinho et al., 2020).

Most market participants believe in an irreversible digitalisation of the construction industry and the resulting consequences for those who do not participate in this progress (Vihmo \& Salo, 2020).

Despite all of this, 4 out of 10 companies do not have a long-term digitalisation strategy in Switzerland, facing the most important obstacle on dealing with discontinuities in technology and their corresponding processes, which every second respondent sees as a major challenge - not only the classic source of error, but also a loss of efficiency (Binder \& Giger, 2020). However, it is important not only to digitize existing processes, but also to rethink the value chain and ensure business continuity (Contzen, 2020). Yet, there are only a small number of small and medium-sized companies, however, that are able to make these mostly costly investments (Desruelle et al., 2019). Surprisingly, according to Eurostat $94 \%$ of all construction enterprises have less than 10 employees (Eurostat, 2020). It can be stated that these smaller companies are mostly lack on the experience about the customer needs, the market an competition and therefore a low customer centric approach (Kaschny). Most construction companies do not appear to consider fundamental principles of effective marketing, the so called 4 P of marketing: Product, Price, Promotion and Placement (Jobber, 2010). The majority of these smaller construction companies live on word of mouth (Blazevic et al., 2013) and active referrals from existing customers. Hence, there are two essential factors for the price assertiveness of a company: the perceived customer benefit and the brand (Flatscher, 2018) - with most of the construction companies only well-known to construction professionals. Since most of the smaller companies primarily work as subcontractors for larger companies and focussing on a mostly limited regional area, they will face liquidity problems more swiftly and are highly likely to go into liquidation (Parada, 2020). Insolvency rates of $10 \%$ or more have already been reported from individual countries (Global Construction Review, 2020).

Nonetheless, there is also a possible solution to promote digitisation. Property technology ("PropTech") companies, often referred to as digital fig leaves for the construction industry, are not immune to the crisis and have partly serious financial problems. This for manifold reasons; due to the start-up mentality, the financial resources are scarce and result in a short-term ability to cover liabilities. Moreover, essential financing rounds were not carried out due to COVID-19. Notwithstanding, the interest in new technologies offered by these PropTech companies are increasing but will result in a consolidation with a lower number of companies (Credit Suisse AG, 2020b). Yet, the effects of this digitalisation approaches will not be seen before a time period of 12 to 18 months (Donati, 2020). However, it must be considered that PropTechs often only work on small sections in a project and do not have the entire digitization or the whole project in view. Therefore, the utilisation of PropTechs sometimes leads to a higher number of interfaces between project participants and are only a shortterm solution, among other things due to the fact that it is not known how long the company will exist (compare Beyerle \& Nolan, 2020 and Rodeck et al., 2019).

\section{Black or White Swan in Relation to Construction?}

Some participants point out that a pandemic is nothing new in history but has occurred at least three times per century on average with $90 \%$ of the bacteria and viruses not known thirty years ago. Human kind has to prepare for this challenge (Brehon, 2020). Consequently, advocates argue that 
COVID in general is not a Black Swan as the development of spreading was foreseeable and human mankind should have been prepared for it (Taleb \& Spitznagel, 2020; Uhlig, 2020). Resulting, COVID-19 cannot be considered to be a "Black Swan" which is a highly improbable event with the three characteristics of unpredictability, generating a massive impact and after the fact, people tend to concoct an explanation that makes it appear less random (Taleb, 2007). However, this general statement is not sufficiently meaningful for all economic sectors as they do not have the same digital, financial and organisational maturity to cope with crises. COVID-19 is predestined to play a leading role at this crucial point in history and will probably change established customs, break and reshape several links of the analogue-based value chain. There are several unparalleled market turmoil's amongst others Brexit, trade wars between the United States and China, uncertain energy supply due to sustainability efforts and the oil war (Dempsey, 2020) and the recession respectively depression based on the circumstances of COVID-19. Considering this, it may be considered a Black Swan for the construction industry, as the usual crises reaction of massive subsidy payments will not be sufficient and not adequate to prepare the industry for following crises. The construction industry in its highly fragmented, mostly geographically limited location, a low performance measurement (Ahmad et al., 2016) the predominately used analogue methods, and the lack of digitisation capability of the companies is not able to cope with this crisis by itself. Asymmetric information and uncertainty, cost overruns and defaults are all ubiquitous features of the (procurement) process (Birulin, 2020). However, these are global influences influencing severely at a local level, which cannot be controlled in this way and needs a political backing on a transnational level (Donner et al., 2010). Hajikazemi et al., 2016 point to the fact that there are two possible solution to handle these Black Swans: either through prediction or dealing with their circumstances. These cyclical movements are the rule in the construction sector (Kapelko et al., 2014), but still market participants are not or not well prepared to cope with these regular wave movements. It should be noted that these impacts cannot be planned for by all participants, as most of them do not have all the knowledge necessary for this situation, nor do they have financial resources to consider all eventualities. However, the individual response is subjective and can be proactive, so a degree of foresight is compulsory (Silva, 2013). Although this crisis is taking place on an international level, it has a very large impact on local conditions and leads to a general behaviour of indifference, since it is firmly believed that nothing can be done to change it.

\section{COVID-19 and the European Green Deal as a Digital Impetus for the European Economic Area?}

The pandemic is also seen as a blueprint for the coming climate change that will affect the world in a few years' time and for which the supply chain is hardly or only partially prepared (Badre \& Tiberghien, 2020 amongst others). The long-term environmental policy orientation could be one reason why way before the COVID-19 related crisis, the European Union has drafted a digital transformation plan, based on disruptive technologies, such as additive manufacturing, automation, drones, Building Information Modelling (BIM) and Virtual/Augmented Reality amongst others (Desruelle et al., 2019). The European standardisation bodies CEN and CENELEC have accelerated their processes and procedures in order to implement corresponding directives, standards and initiatives on the level of sustainability more quickly and in a more targeted manner. To this end, a strategic plan for the digital transformation of standardisation has been drawn up, which not only aims to implement standardisation per se, but also to accompany and accelerate the digital transition of the industry (Missiroli, 2020).

It was the aim of enabling the digital transformation in construction on a European Level, as almost $6 \%$ of all employees in the European Union are engaged in the construction industry. Yet, obviously, only a minority see this crisis as an digital impetus for the construction industry. (Heinz \& Gibson, 2020). Mostly, criticists proclaim that the mindset of decision-making bodies have not been changed and remain in the "old habitus", we are not stepping out of our personal comfort-zone and eventually, even changes to digital needs time (Cachelin, 2020). In Switzerland, this pandemic crisis is considered the enabler of a "Digital New Deal" - without using the buzzword "Digital Transformation". It can 
be considered the biggest experiment in the short history of the digital era (digitalswitzerland, 2020). Considering the definition of "Digital Transformation" as the direct and indirect effect of the use of digital technologies and techniques on organisational and economic conditions on the one hand and new types of products and services on the other (Pousttchi, 2020), it rapidly emerges that the changes will be profound, including in the construction industry.

The European Union has announced that it is giving high priority to the analysis in their work programme of whether the EU should adopt national strategies for digitisation of the industry and in supporting "Digital Innovation Hubs" to promote digital innovation. The result of this investigation shall be published as soon as possible and is not yet available (European Court of Auditors). Up to now, construction or real estate is not explicitly named in most of these documents. On Swiss level, the digital strategies rarely mentions or even considering the construction industry (BAKOM, 2018/2018; Bundesamt für Kommunikation, 2016; digitalswitzerland, 2017; economiesuisse, \& WIRE Think Tank, 2017; Tucci et al., 2016). Compared on a transnational level, the first attempts to answer this crisis were taken with an investment plan still planned for construction (Government of Ireland, 2020).

The so called "European Green Deal Investment Plan" (European Commission, 2020b) (hereinafter Investment Plan) can be considered to be a new Marshal Plan with immense investments - over 1 Trillion Euro shall be invested in total in the next ten years (Harvey \& Rankin, 2020). It shall prepare the European Union for the future challenge and make it more robust for crisis. The Plan could has the potential to be a driving source for starting the next industrial revolution (Deutscher Naturschutzring, 2020). The main ambition is to become the first climate neutral continent with the three aims of reducing net emissions of greenhouse gases by 2050 to zero, economic growth is decoupled from resource use and no person and no place is left behind (European Commission, 2020c). The additional investments required to reach a $34 \%$ share [of renewable energies] by 2030 [and further on] would help Europe maintain its leading role while deriving substantial macroeconomic benefits in terms of growth and balance of trade, as well as creating a new industrial base around the renewables sector (International Renewable Energy Agency, 2018). Three years before the Investment Plan was launched at the European level, the first attempts were made in Switzerland to use the digital transformation to create a "new green economy" (Noser, 2017) with a budget of CHF 2 billion to foster sustainable innovation and the therefore digital prerequisites.

Strangely, the construction industry respectively the real estate sector is not directly mentioned in this Investment Plan and does not take over responsibilities. Indirectly, however, the industry is referred to briefly in terms of the circular use of materials (European Commission, 2020a), resource management and education (European Commission, 2020b), but without going into further elaboration. It is further noted that these measures are not limited to one industrial sector in this Investment Plan and are of a general nature. Construction industry is mentioned in the actions to be taken (Adler et al., 2019), namely housing, infrastructure and utility supplies: mostly focussing on modernisation and renovation activities. It should be considered that every Swiss Franc spent in modernisation generates at least 2.2 times the downstream value added (Bundesamt für Energie BFE, 2018). The building stock in Switzerland has an estimated replacement value of CHF 2.380 trillion (Gerum et al., 2011), the stock in Germany an estimated EUR 11.800 trillion (Deutscher Bundestag, 2017) .The built assets represent an enormous value, and it must be constantly maintained and adapted to new requirements due to sustainability. The maintenance and renewal costs in Switzerland alone will amount to CHF 65 billion or 12 percent of gross domestic product annually over the next two decades (Gerum et al., 2011). Taking the same calculation basis for Germany, it is obvious that the sums involved are very substantial and will certainly help to drive towards full employment - this with a certain time lag, as the construction industry reacts anticyclically and with a delay to investment programmes (Otto \& Ditzen, 2019). However, this Plan the construction industry to a limited extent in the application of new methods and technologies, since it is usually a matter of optimising existing systems and plants or of specifically repairing components such as replacing windows or insulation. Nevertheless, looking at the building stock in Switzerland, for example, it swiftly becomes apparent 
that a large proportion of the buildings were erected before 1980 and are now considered to be in need of renovation (Gerum et al., 2011). Notwithstanding, this is independent from the Investment Plan, but welcomed as supporting measure for the accelerated implementation of the renovations.

\section{The Conundrum of Reluctance to Change for the Industry}

The European Investment Plan promotes the adaptation and implementation of latest state-of-theart-techniques and technologies. Implementing newly developed digital methods - which at times have not been tested continuously and comprehensively along the value and supply chain - in a primarily analogously and project led industry cannot be a designated goal. It must be considered that experience shows that 70 to 90 percent of intrapreneurship efforts fail because the ideas are usually not critically scrutinised. Governance and its combination with innovation can be encapsulated within the contemporary governance term, "resilience," where resilience is defined as "an organization's capacity to anticipate and react to change, not only to survive, but also to evolve." (Pearce, 2018). Data Governance frameworks such as COBIT (ISACA, 2019) although established in other industries for years, are relatively unknown to the construction industry (Chen \& Wang, 2011).

Though, considering the suggested Investment Plan, there are several evolved challenges, which must be dealt with. It must also be contemplated that there is a plethora of many individual measures that are strongly interwoven. They are set screws that are not turned on their own, but are viewed, analysed and finally implemented in a holistic approach. From the plethora of measures, there are only a few listed here that can be quickly implemented by the industry if a jointly agreed approach is taken. However, it must be considered that there are at least five steps which must be implemented (Pearce, 2018). After clarifying the scope of innovation and ensuring the effectiveness, the focus must be on resilience, ensuring the sustainability and the growing concern of the organisation. Thirdly, the implications and risks of the preferred model for organisational innovation must be understood to fourthly, focusing on value, ensuring the right degree of financial resource made available for operationalisation. Fifthly, it must be ensured that the implementation of new technology can not only be integrated into the organisation, but that the new technology is also without alternative most effective in supporting the organisation's strategy (Pearce, 2018). However, there are three main barriers to innovation: lack of transparency, improper resource allocation and a lack of innovation culture (Tencer, 2015). Considering an industry in which most companies spend less than $1 \%$ of their revenues in research and development and less than $1 \%$ of revenues in information technology, it is apparent that this industry is not well prepared for innovation (Agarwal et al., 2016).

Considering the different lifecycle phases and requirements of the different stakeholder, it is getting obvious that every participant has a divergent view on the built asset (Herr et al., 2020). This is habitually not taken into account in the project management of construction projects, as these are usually carried out in rigid, time-limited phases (Albrecht, 2014). In many projects, planners and contractors are often commissioned for a very limited period or for a very specific technical or planning part. The data or plans of the previously commissioned companies must be taken over by the later commissioned planner, which was the rule in construction projects. This approach leads very strongly to information discontinuities and an unusually high flexibility of the planners, since they check the previous planning services in addition to their own planning services and if necessary, update them to the technically correct status. In this way, a very strongly construction phase-oriented thinking is promoted, in which the further, subsequent phases are disregarded. (Albrecht, 2014; Wildenauer, 2016b)

Another main challenge is the current practice of tendering, which requests that the planners and contractors list precisely before the execution what they intend to implement later (Heidemann, 2011). With new contract models, which are primarily derived from American contract law (such as Partnering, Construction Management or Guaranteed Maximum Price GMP), the aim is to develop an optimized performance within a fixed cost framework during planning and execution through goal-oriented and open cooperation between client, planners and contractors (Girmscheid, 
2006). However, these forms of cooperation must first be developed for a broader basis and become established accordingly. Yet, studies from Australia and the United States showed that "[alliance based] approaches and the associated newly developed forms of contract and awarding procedures have enabled the projects to better achieve their objectives and have led to substantially improved project successes overall. A prerequisite for this was that the executing organisations, which were involved at an early stage, were encouraged by an incentive system to reduce the project costs while at the same time improving the quality." (Fischer et al., 2017; Heidemann, 2011; Jones, 2014). All parties involved in a specific construction project must learn to implement new contractual methods in a goal- and benefit-oriented manner.

However, construction seems to be at crossroads - research based universities are not able to cope with the demand on the technology site or to put simply, educational institutes are often not in a position to satisfy the needs of companies for experienced engineers who think holistically technologically, methodically and "beyond the horizon".(Loosemore, 2020). This will appear to become a transnational economic problem, as specifications are currently being driven forward very strongly by the educational landscape (Wildenauer, 2018a). Additionally, there is often no quality control for construction worker education. There is often the view that anyone can work on the construction site and is sure to find a placement. However, there is not a short-term solution to it. There is certainly a need for a complete change in the primary and postgraduate education and skills of employees. It is depending if the construction industry want to innovate for the sake of innovation or for a real progress (Buchner, 2020) - it is not about being innovative but about bringing the innovation to the building site respectively into the construction sector. This could be implemented with lean management approaches, which have been researched for years in the construction industry and which are ideally suited due to the current Taylorism of the industry. However, a final breakthrough of this approach has yet to be achieved (Andujar-Montoya et al., 2019).

It should be noted, however, that it is not enough to apply this innovation in a specific life cycle phase, such as construction or planning. The parties involved in these phases are interdependent and need corresponding information for the further development of the asset to be built from each other. A continuous digital data flow for all phases from planning to maintenance and demolition would have substantial savings for all participants (Barber, 2005; Olsson et al., 2019). Although the development of computer technology has rapidly entered many industrial sectors, interoperability between the individual file formats of construction-specific programs, such as CAD (Computer Aided Design) and BIM (Building Information Modelling) programs, is rarely given. Data exchange is often only possible with great human effort, intensive coordination and reworking (Wildenauer, 2016a).

Examining the entire life cycle and the requirements of building owners and operators, it is noticeable that these often do not change even with newly developed and rapidly introduced methods. What does change is the ordering, checking and further processing of (ordered) data, which is now handed over from planners and contractors to building owners and operators. Building owners are usually not in a position to keep up with technological developments (compare Fejfarová \& Urbancová, 2015 and Ammar et al., 2019 amongst others). Furthermore, it is a rarity that building applications and documents relevant to construction can be transmitted digitally to planning and building authorities. In Switzerland, the Tallinn Declaration to a complete e-Governance is to be implemented by 2022, which intends to implement the following packages by 2022 :

1. Digital by default,

2. Once-only,

3. Trustworthiness and security,

4. Openness and transparency,

5. Interoperability by default (Fialla, 2019).

A long way to go for the construction industry yet short time. 
There are various approaches to this in Germany, but all of them are in the development stage, without it being possible to assume that they can be implemented within a short time (König, 2018). The points to be examined by the respective building authorities or the further proceedings after the processing and checking of data at the authority are plainly too extensive to include all of them in these approaches.

Several participants must contribute to the digital impetus of the construction industry, such as planners, contractors, clients, Universities and educational promoters, trade associations and federations, software vendors and technology suppliers, Governments on national, transnational and international levels and most importantly, People working in the industry - with all having different agendas and needs to be reconciled. This will be one of the most important obstacles in modern industrial history.

\section{CONCLUSION AND RECOMMENDATION}

It is inevitable that the construction industry will have to make a big step towards a digital change. However, this change neither be driven by a single person, nor company, nor institution nor a university; it requires a common focus on medium and long-term goals and a shared view of value creation. The pandemic has led to many processes being carried out more quickly than anticipated, but not an overall approach. This is reflected, for example, in the accelerated development and increased acceptance of remote meetings. Due to distance and hygiene regulations, planning services had to be carried out from home or increasingly on an interdisciplinary basis. Physical distances were shortened or eliminated with the help of digital tools. Nevertheless, this is only a first step, as the further process steps such as implementation are still affected by the digital change. Increased efforts must be made in these implementation processes, such as physical construction on and off site. The construction industry must do its homework and invest in the necessary technologies: communication, collaboration and coordination platforms, data and information management. More important, however, the construction industry must take a concrete approach to change and bundle the different levels of digital maturity. Those involved in a construction project shall learn to cooperate and focus on the entire life cycle of a building or asset. The construction industry is called upon not to maintain the status quo but to modernise the entire industry continuously and permanently. Every participant in the value chain must contribute to this - even with small steps. Only by doing so this industry's digital transformation will succeed. However, it will be a long and arduous journey instead of a sudden turnaround. 


\section{REFERENCES}

Adler, Wargan, \& Prakash. (2019). The Green New Deal for Europe: Blueprint for Europe's Just Transition [Edition II]. Retrieved May 23, 2020, from https://report.gndforeurope.com/cms/wp-content/uploads/2020/01/ Blueprint-for-Europes-Just-Transition-2nd-Ed.pdf

Agarwal, Chandrasekaran, \& Sridhar. (2016). Imagining construction's digital future. Retrieved December 07, 2019, from https://www.mckinsey.com/ /media/McKinsey/Industries/Capital\%20Projects\%20and\%20 Infrastructure/Our\%20Insights/Imagining\%20constructions\%20digital\%20future/Imagining-constructionsdigital-future.ashx

Ahmad, S., Svalestuen, F., Andersen, B., \& Torp, O. (2016). A Review of Performance Measurement for Successful Concurrent Construction. Procedia: Social and Behavioral Sciences, 226, 447-454. doi:10.1016/j. sbspro.2016.06.210

Albrecht. (2014). Building Information Modeling (BIM) in der Planung von Bauleistungen. Teilw. zugl.: Dresden, Techn. Univ., Dipl.-Arbeit, 2013 u.d.T.: Building Information Modeling (BIM) zur Sicherstellung der Datendurchgängigkeit in der Planung von Bauleistungen. Disserta-Verl./Diplomica-Verl. http://www.hausarbeiten. $\mathrm{de} / \mathrm{faecher/vorschau/264391.html}$

Alessi, B., Campolongo, C., \& Manca, M. (2020). The Resilience of EU Member States to the Financial and Economic Crisis. Social Indicators Research, 148(2), 569-598. doi:10.1007/s11205-019-02200-1

Alreshidi, M., Mourshed, M., \& Rezgui, Y. (2017). Factors for effective BIM governance. Journal of Building Engineering, 10, 89-101. doi:10.1016/j.jobe.2017.02.006

Altman. (2020, May 20). Will Covid-19 have a Lasting Impact on Globalization? Retrieved May 23, 2020, from https://hbr.org/2020/05/will-covid-19-have-a-lasting-impact-on-globalization

Ammar, Underwood, \& Al Shawi. (2019). Critical success competencies for the BIM implementation process: UK construction clients. Journal of Information Technology in Construction, 24, 80-94. https://www.itcon.org/2019/5

Andujar-Montoya, Rizo-Maestre, \& Echarri-Iribarren. (2019). BIM and Lean Construction interactions: A state of the art review. In WIT Transactions on The Built Environment, Building Information Modelling (BIM) in Design, Construction and Operations III (pp. 1-13). WIT Press.

Árnandóttir. (2019). BIM Maturity in Iceland: A study of contractors and sub-contractors (TRITA-ABEMBT-19397) [Master of Science Thesis]. Royal Institute of Technology, Stockholm. https://www.diva-portal. org/smash/get/diva2:1335600/FULLTEXT01.pdf

Artenie. (2020). EU countries measures on COVID-19 under magnifying glass. Retrieved June 06, 2020, from https://www2.deloitte.com/content/dam/Deloitte/ro/Documents/COVID-19\%20CE\%20Measures-version\%20 11.pdf

Asyali \& Bastug. (2014). Influence of scientific management principles on ISM Code. Safety Science, 68, 121-127. 10.1016/j.ssci.2014.03.011

Azoulay \& Jones. (2020). Beat COVID-19 through innovation. Science, 368(6491), 553. 10.1126/science.abc5792

Badré \& Tiberghien. (2020). The Pandemic Must End Our Complacency. Retrieved June 21, 2020, from https:// www.project-syndicate.org/commentary/covid19-pandemic-crisis-of-globalization-international-leadership-bybertrand-badre-and-yves-tiberghien-1-2020-06

BAKOM. (2018). Aktionsplan Digitale Schweiz. Retrieved October 13, 2019, from https://www.bakom.admin. ch/dam/bakom/de/dokumente/informationsgesellschaft/strategie2018/Aktionsplan\%20Digitale\%20Schweiz.pdf. download.pdf/Aktionsplan\%20Digitale\%20Schweiz_DE.pdf

Balcerzyk, Ledzianowski, \& Siczek. (2019). Fluctuation of employees in construction company as a measurable phenomenon. In AIP Conference Proceedings, Central European Symposium on Thermophysics 2019 (CEST). AIP Publishing. 10.1063/1.5114166

Barber. (2005). Understanding internally generated risks in projects. International Journal of Project Management, 23(8), 584-590. 10.1016/j.ijproman.2005.05.006 
Barbosa, W., Mischke, R., Sridhar, P. B., \& Brown. (2017). Reinventing Construction: A route to higher productivity. McKinsey. Retrieved January 25, 2019, from McKinsey: https://www.mckinsey.com/industries/ capital-projects-and-infrastructure/our-insights/reinventing-construction-through-a-productivity-revolution

Baublatt. (2020). Bauhauptgewerbe: 20.7 Milliarden Franken Umsatz in 2019. Retrieved February 29, 2020, from https://www.baublatt.ch/baubranche/bauhauptgewerbe-207-milliarden-franken-umsatz-im-2019

Baumeisterverband, S. (2020, May 27). Corona bremst Bauhauptgewerbe [Press release]. http://www.baumeister. $\mathrm{ch} /$ de/news/497-medienmitteilungen/3732-corona-bremst-bauhauptgewerbe

Bellido-Montesinos, L.-G., Lozano-Galant, F., Castilla, F. J., \& Lozano-Galant, J. A. (2019). Experiences learned from an international BIM contest: Software use and information workflow analysis to be published in: Journal of Building Engineering. Journal of Building Engineering, 21, 149-157. doi:10.1016/j.jobe.2018.10.012

Bertschek, Niebel, \& Ohnemus. (2019). Zukunft Bau - Beitrag der Digitalisierung zur Produktivität in der Baubranche: Endbericht http://ftp.zew.de/pub/zew-docs/gutachten/ZukunftBau_BBSR_Endbericht2019.pdf

Beyerle \& Nolan. (2020). Real Estate \& PropTech 2019/2020 - Standortbestimmung. Retrieved June 21, 2020, from https://www.catella.com/globalassets/global/mix-germany-corporate-finance/catella_mt_proptech_nov19. pdf

Binder \& Giger. (2020). Marktstudie: Digitalisierung und Nachfolgeregelung von IT-Altsystemen. Retrieved June 26, 2020, from https://avelts.com/comitas/201909_Marktstudie_Digitalisierung_IT\%20Altsysteme.pdf

Birulin. (2020). Optimality of simple procurement auctions. International Journal of Industrial Organization, 70, 102610. 10.1016/j.jindorg.2020.102610

Blazevic, H., Garnefeld, R., \& Keiningham, A. (2013). Beyond traditional word-of-mouth. Journal of Service Management, 24(3), 294-313. doi:10.1108/09564231311327003

Bordeleau \& Felden. (2019). Digitally transforming organisations: a review of change models of Industry 4.0. In ECIS 2019 Proceedings: Proceedings of the 27th European Conference on Information Systems (ECIS) (pp. 1-14). ECIS. https://aisel.aisnet.org/ecis2019rp/49

Brehon. (2020). The European Union and the Coronavirus: Fondation Robert Schuman Policy Paper. Fondation Robert Schuman. Retrieved May 23, 2020, from Fondation Robert Schuman: https://www.robert-schuman.eu/ en/european-issues/0553-the-european-union-and-the-coronavirus

Buchenau \& Hofmann (2020, June 2). Heidelbergcement ist wegen der Coronakrise im Sparmodus. Handelsblatt. https://www.handelsblatt.com/unternehmen/industrie/bilanzcheck-heidelbergcement-ist-wegen-der-coronakriseim-sparmodus/25879482.html

Buchner. (2020). Innovation der Innovation wegen oder für wirklichen Fortschritt? Retrieved June 25, 2020, from https://solidbau.at/a/innovation-der-innovation-wegen-oder-fuer-wirklichen-fortschritt

Bundesamt für Energie BFE (Ed.). (2018). Jahresbericht 2018: Das Gebäudeprogramm. https://www. dasgebaeudeprogramm.ch/media/filer_public/e1/8d/e18d8463-2fb0-4a1b-b185-6301dfe91a27/bfe_ gebaudeprogrammjahresbericht_de_190909.pdf

Bundesamt für Kommunikation (Ed.). (2016). Digital Switzerland strategy: Edition 2016. https://www.bakom. admin.ch/dam/bakom/en/dokumente/bakom/digitale_schweiz_und_internet/Strategie\%20Digitale\%20Schweiz/ Strategie/Strategie\%20Digitale\%20Schweiz.pdf.download.pdf/digital_switzerland_strategy_Brochure.pdf

Bundespresseamt. (Ed.). (2020). Halten Sie Abstand - Regeln, Einschränkungen, Lockerungen: Bund-LänderBeschluss vom 06. Mai. Bundespresseamt. https://www.bundesregierung.de/breg-de/themen/coronavirus/ corona-massnahmen-1734724

Bundestag, D. (Ed.). (2017). Unterrichtung durch die Bundesregierung: Dritter Bericht der Bundesregierung über die Wohnungs- und Immobilienwirtschaft in Deutschland und Wohngeld- und Mietenbericht 2016. Drucksache 18/13120. Deutscher Bundestag. https://digitalswitzerland.com/wp-content/uploads/2017/01/ Digitales-Manifest-CH-D.pdf

BWO. (2020). Coronavirus: Massnahmen im Mietrecht. Bundesamt für Wohnungswesen BWO. Retrieved July 06, 2020, from Bundesamt für Wohnungswesen BWO: https://www.bwo.admin.ch/bwo/de/home/mietrecht/ coronavirus.html 
Cachelin. (2020). Covid19 - Warum alles gleich bleibt. Wissensfabrik. Retrieved June 21, 2020, from Wissensfabrik: https://www.wissensfabrik.ch/allesbleibtgleich/

CCSA (Ed.). (2020). How COVID-19 is changing the world: a statistical perspective. Committee for the Coordination of Statistical Activities. https://www.wto.org/english/tratop_e/covid19_e/ccsa_publication_e.pdf

Chen \& Wang. (2011). IT Governance of Construction Information Based on COBIT Model. In M. Zhou (Ed.), Communications in Computer and Information Science. Education and Management (Vol. 210, pp. 14-20). Springer Berlin Heidelberg. 10.1007/978-3-642-23065-3_3

CIA. (2021). World Factbook: Country: Switzerland. Retrieved January 15, 2021, from https://www.cia.gov/ the-world-factbook/countries/switzerland

CIOB. (2014). Code of practice for project management for construction and development (5th ed.). Wiley Blackwell. http://swbplus.bsz-bw.de/bsz41491337xcov.htm

Contzen. (2020). Accelerate digitization to increase resilience: A global COVID-19 response for legal leaders. https://www2.deloitte.com/content/dam/Deloitte/global/Documents/Legal/dttl-legal-covid-respond-legaldigitization.pdf

Cox, Ireland, \& Townsend. (2006). Managing in construction supply chains and markets: Reactive and proactive options for improving performance and relationship management. Thomas Telford.

Credit Suisse, A. G. (2020a, June 15). Coronakrise: Was bedeuten die Staatsschulden für die Schweiz und ihre Wirtschaft? [Press release]. https://www.credit-suisse.com/media/assets/private-banking/docs/ch/unternehmen/ unternehmen-unternehmer/publikationen/monitor-schweiz-q2-2020-de.pdf

Credit Suisse AG. (2020b, June 15). COVID-19: Boom oder Bust für PropTechs? Swiss PropTech Report 2020 [Press release]. Author.

da Silva, S. L. (2019). An ontology for interoperability assessment: A systemic approach. Journal of Industrial Information Integration, 16, 1-13. doi:10.1016/j.jii.2019.07.001

Dahm \& Fischer. (2020). Das Virus lässt die Wirtschaft abstürzen. Retrieved June 19, 2020, from https://www. gtai.de/gtai-de/trade/specials/das-virus-laesst-die-wirtschaft-abstuerzen-237304.pdf

Dempsey. (2020). How Europe Should Prepare for the Post-Coronavirus World: Judy Dempsey's Strategic Europe. Retrieved June 21, 2020, from https://carnegieeurope.eu/strategiceurope/82016\#comments

Desruelle, B., Bono, B., Delipetrev, D. B., Macias, F., Gkoumas, J., Kalpaka, N., de Lima, N., Pagano, P., Martin, S., \& Sobolewski, T., \& Brancati, U. (2019). Digital Transformation in Transport, Construction, Energy, Government and Public Administration: JCR Science for Policy Report (1st ed.). https://publications.jrc.ec.europa. eu/repository/bitstream/JRC116179/jrc_digital_transformation_final_on_line_en_baja_resoluci\%c3\%b3n_online. pdfhttps://doi.org/10.2760/68920010.2760/689200

digitalswitzerland. (Ed.). (2020). \#Covid19 Five Opportunities for the Digital Transformation in Switzerland. https://digitalswitzerland.com/covid-19-whitepaper-on-opportunities-for-digital-transformation-in-switzerland/

Donati. (2020). What's Next For Real Estate And Proptech After Covid-19? Retrieved June 21, 2020, from https://www.forbes.com/sites/angelicakrystledonati/2020/05/27/whats-next-for-real-estate-and-proptech-aftercovid-19/\#1f2a71a76940

Donner, Hartmann, \& Kuhn. (2010). Die Krise bewältigen: Eine vergleichende Analyse politischen Managements in 14 Ländern. Retrieved January 15, 2021, from https://www.bertelsmann-stiftung.de/fileadmin/files/ BSt/Presse/imported/downloads/xcms_bst_dms_31217_31249_2.pdf

economiesuisse; WIRE Think Tank. (2017). Zukunft digitale Schweiz: Wirtschaft und Gesellschaft weiterdenken [Press release]. www.economiesuisse.ch

Egan. (1998). Rethinking Construction: Report of the Construction Task Force. http://constructingexcellence. org.uk/resources/rethinking-construction-the-egan-report/

Eken, B., \& Birgonul, D. (2015). A Lessons Learned Database Structure for Construction Companies. Procedia Engineering, 123, 135-144. https://doi.org/10.1016/j.proeng.2015.10.070 
European Commission. (2020a). Circular Economy Action Plan: The European Green Deal. Retrieved June 21, 2020, from https://ec.europa.eu/commission/presscorner/api/files/attachment/863182/EU_Greendeal_Circular_ economy_en.pdf.pdf

European Commission. (2020b). Communication from the Commission to the European Parliament, the Council, the European Economic and Social Committee and Committee of the Regions: Sustainable Europe Investment Plan - European Green Deal Investment Plan. https://eur-lex.europa.eu/legal-content/EN/TXT/PDF/?uri=CE LEX:52020DC0021\&from $=$ EN

European Commission. (2020c). A European Green Deal: Striving to be the first climate-neutral continent. Retrieved June 21, 2020, from https://ec.europa.eu/info/strategy/priorities-2019-2024/european-green-deal_en

European Court of Auditors. (Ed.). (2020). Work Programme: COVID-19 update and revision. https://www.eca. europa.eu/Lists/ECADocuments/WP2020_REVISED/WP2020_REVISED_EN.pdf

European Court of Auditors. (2020, June 16). Speed up cross-border megaprojects to optimise transport across Europe, say EU Auditors [Press release]. https://www.eca.europa.eu/Lists/News/NEWS2006_16/ INSR_Transport_Flagship_Infrastructures_EN.pdf

European International Contractors (Ed.). (2020). European Development Finance Institutions (DFI) and Export Credit Agency (ECA) Responses to COVID-19. Database (Oxford). Retrieved June 25, 2020, from https://www. eic-federation.eu/sites/default/files/paragraph-files/eic_overview_eca_dfi_covid-19_responses_0.xlsxhttps:// www.eic-federation.eu/sites/default/files/paragraph-files/eic_overview_eca_dfi_covid-19_responses_0.xlsx

Eurostat. (Ed.). (2020). Construction by employment size class: (NACE Rev. 2, F). European Statistical Office. http://appsso.eurostat.ec.europa.eu/nui/show.do?dataset=sbs_sc_con_r2\&lang=en20

Fabig \& Haasper. (2016). IT Management: Erfahrungen und Trends. Books on Demand.

Farman. (2020). Wenn Millionen hinter Milliarden verschwinden: Allgemeine Covid-Unterstützungsmassnahmen fördern und Ungleichbehandlung vermeiden. Retrieved June 22, 2020, from https://www.avenir-suisse.ch/wennmillionen-hinter-milliarden-verschwinden/

Fejfarová \& Urbancová. (2015). Application of the competency-based approach in organisations in the Czech Republic. E+M Ekonomie a Management, 18(1), 111-125. 10.15240/tul/001/2015-1-009

Feld, Schulten, Simons, Wandzik, \& Gerling. (2020). Frühjahrsgutachten Immobilienwirtschaft 2020 des Rates der Immobilienweisen. https://www.zia-deutschland.de/fileadmin/Redaktion/Marktdaten/PDF/Fru hjahrsgutachten_Immobilienwirtschaft_2020.pdf

Feriel, B. (2018). Investigating the Synergy of Integrated Project Delivery and Building Information Modeling in the Conservation of the Architectural Heritage. Journal of Contemporary Urban Affairs, 2(3), 67-77. doi:10.25034/ijcua.2018.4720

Fialla. (2019, June 19). Tallinn-Deklaration zu E-Government. Wo steht die Schweiz heute, und was ist zu tun? Curia Vista der Bundesversammlung Bern 19.3686. https://www.parlament.ch/de/ratsbetrieb/suche-curia-vista/ geschaeft?AffairId=20193686

Fischer, Reed, \& Ashcraft. (2017). Integrating project delivery. John Wiley \& Sons Inc. http://search.ebscohost. com/login. aspx ?direct $=$ true $\&$ scope $=$ site $\& d b=$ nlebk $\& A N=1475501$

Flatscher. (Ed.). (2018). bau+immobilien Report: Die Unternehmensmarke: viel ungenütztes Potenzial. Report, 21(03). Wien. Report. https://www.report.at/ifile/2018_03_bau.pdf

Flyvbjerg. (2007). Cost Overruns and Demand Shortfalls in Urban Rail and Other Infrastructure. Transportation Planning and Technology, 30(1), 9-30. 10.1080/03081060701207938

Flyvbjerg, Skamris Holm, \& Buhl. (2002). Underestimating Costs in Public Works Projects: Error or Lie? Journal of the American Planning Association, 68(3), 279-295. 10.1080/01944360208976273

Flyvbjerg, Skamris Holm, \& Buhl. (2003). How common and how large are cost overruns in transport infrastructure projects? Transport Reviews, 23(1), 71-88. 10.1080/01441640309904 
France24. (2020). Covid-19 - lockdown exit strategies in the EU: uncoordinated measures for uncoordinated results? Interview with Alberto Alemanno [Video]. https://www.france24.com/en/video/20200427-covid-19lockdown-exit-strategies-in-the-eu-uncoordinated-measures-for-uncoordinated-results

Fredenlund, Mercer, \& Blonk. (2020). Digital Supply Chains - Data Driven Collaboration: Digital Supply Chains in the Built Environment. Retrieved May 23, 2020, from https://cobuilder.com/en/the-digital-supplychain-data-driven-collaboration/

Funk. (2020, May 20). Swiss construction and Covid-19. Retrieved June 25, 2020, from http://www.euroconstruct. org/jart/prj3/wifo/main.jart?rel=euroconstruct_en\&reserve-mode=active\&content-id=1590465618766\&pushfile $=1481829819957$

Gallaher, O'Connor, Dettbarn, \& Gilday. (2004). Cost Analysis of inadequate Interoperability in the US Capital Facilities (NIST GCR 04-867). 10.6028/NIST.GCR.04-867

Gao \& Pishdad-Bozorgi (2019). BIM-enabled facilities operation and maintenance: A review. Advanced Engineering Informatics, 39, 227-247. 10.1016/j.aei.2019.01.005

Gardiner. (2014, June 27). Latham's report: Did it change us? Retrieved June 20, 2020, from https://www. building.co.uk/focus/lathams-report-did-it-change-us/5069333.article

Gehring, Lux, Tietz, Waibel, \& Weis (2017). Digitalisierung in Schweizer Klein- und Mittelunternehmen: KMU-Spiegel 2017. www.fhsg.ch/ifu

Gerum, Schalcher, Boesch, Bertschy, Matter, \& Jakob. (2011). Was kostet das Bauwerk Schweiz in Zukunft und wer bezahlt dafür? [Fokusstudie NFP 54]. vdf Hochschulverlag AG an der ETH Zürich.

Girmscheid. (2006). Strategisches Bauunternehmensmanagement: Prozessorientiertes integriertes Management für Unternehmen in der Bauwirtschaft. Springer.

Global Construction Review. (Ed.). (2020). “Can't see beyond three months”: Survey shows Covid impact on construction around the world. Chartered Institute of Building. https://www.globalconstructionreview.com/ news/cant-see-beyond-three-months-survey-shows-covid-im/

Government of Ireland. (Ed.). (2020). Construction Sector Group Building Innovation. https://assets.gov.ie/76845/ c4869acd-5593-4f3b-85a5-895419b90af8.pdf

Grilo, A., \& Jardim-Goncalves, R. (2010). Building information modeling and collaborative working environments. Automation in Construction, 19(5), 521. https://doi.org/10.1016/j.autcon.2009.11.002

Haakestadt \& Friberg. (2017). Deskilling revisited: Labour migration, neo-Taylorism and the degradation of craft work in the Norwegian construction industry. Economic and Industrial Democracy. 10.1177/0143831X17735671

Hajikazemi, Andersen, \& Zidane. (2016). The Black Swan - Knowing the Unknown in Projects. Procedia Social and Behavioral Sciences, 226, 184-192. 10.1016/j.sbspro.2016.06.178

Harvey \& Rankin. (2020). What is the European Green Deal and will it really cost $€ 1$ tn? How the EU's ambitious bid to lead the world on climate action will work and whether it will really make a difference. Retrieved May 23, 2020, from https://www.theguardian.com/world/2020/mar/09/what-is-the-european-green-deal-and-willit-really-cost-1tn

Heidemann. (2011). Kooperative Projektabwicklung im Bauwesen unter der Berücksichtigung von LeanPrinzipien - Entwicklung eines Lean-Projektabwicklungssystems: Internationale Untersuchungen im Hinblick auf die Umsetzung und Anwendbarkeit in Deutschland. Reihe F: Heft 68. KIT Scientific Publishing.

Heinz \& Gibson (2020). BIM-Projektdesign: Die Krise als Chance. Build.-Ing., (3), 18-24. www.build-ing. de/S139

Herr, Lammers, Hakkaja, Stadlbauer, Brodtmann, Grassau, Betz, Hagenschulte, \& Smolka. (2020). Digitale Geschäftsmodelle. Retrieved June 26, 2020, from http://www.zia-digital.de/digitale_geschaeftsmodelle.html

Holtz, Z., Benzell, C., Rahimian, Y., Allen, C., \& Moehring, S. G. (2020, May 20). Interdependence and the Cost of Uncoordinated Responses to COVID-19: Working paper. MIT Sloan School of Management. Retrieved May 24, 2020, from MIT Sloan School of Management: https://mitsloan.mit.edu/shared/ods/documents/?Publ icationDocumentID $=7397$ 
International Renewable Energy Agency. (2018). Renewable Energy Prospects for the European Union. International Renewable Energy Agency (IRENA). https://www.irena.org/-/media/Files/IRENA/Agency/ Publication/2018/Feb/IRENA_REmap_EU_2018.pdf

ISACA. (2019). COBIT 2019 Framework Governance and Management Objectives: COBIT 2019. ISACA.

Jank, Vincenzi, \& Grass. (n.d.). Tiefbauprognosen 2018 - 2030: Tiefbauprognosen 2018 - 2030 Eine Studie von BAK Economics im Auftrag von Infra Suisse. Retrieved June 25, 2020, from https://www.bak-economics.com/ fileadmin/documents/reports/BAK_Economics_Infra_Suisse_Tiefbau.pdf

Jobber. (2010). Principles and practice of marketing (6th ed.). McGraw-Hill.

Jones. (2014). Integrated Project Delivery (IPD) for Maximizing Design and Construction Considerations Regarding Sustainability. Procedia Engineering, 95, 528-538. 10.1016/j.proeng.2014.12.214

Kagermann, Wahlster, \& Helbig. (2013). Recommendations for implementing the strategic initiative INDUSTRIE 4.0: Final report of the Industrie 4.0 Working Group. Federal Ministry of Education and Research. Retrieved September 19, 2020, from Federal Ministry of Education and Research: https://www.din.de/blob/76902/ e8cac883f42bf28536e7e8165993f1fd/recommendations-for-implementing-industry-4-0-data.pdf

Kam. (2016). Key performance indicators: VDC and BIM Scorecard. Leland Stanford Junior University. Retrieved August 09, 2020, from Leland Stanford Junior University: https://vdcscorecard.stanford.edu/vdc-scorecard

Kapelko, M., Oude Lansink, A., \& Stefanou, S. E. (2014). Assessing dynamic inefficiency of the Spanish construction sector pre- and post-financial crisis. European Journal of Operational Research, 237(1), 349-357. https://doi.org/10.1016/j.ejor.2014.01.047

Klinger \& Susong. (2006). The construction project: Phases people terms paperwork processes. Tort Trial and Insurance Practice Section, American Bar Association.

Knitterscheidt. (2020, June 15). In der Bauindustrie geht die Angst vor dem Crash um. Handelsblatt. https:// www.handelsblatt.com/unternehmen/industrie/coronakrise-in-der-bauindustrie-geht-die-angst-vor-dem-crashum/25914298.html?ticket=ST-788156-e6UnasK0DPjf0Bet9VjV-ap1

Knorr, Lebert, \& Houbani. (2020). Offene Immobilienfonds: Marktstudie und Ratings 2020. Retrieved June 17, 2020, from https://www.scopeexplorer.com/Scope\%20Analysis_Offene\%20Immobilienfonds\%202020_ Ratinguebersicht_2020\%20Jun.pdf

Kohler. (2019, September 28). Die deutsche Wirtschaft kann der Schweiz nicht egal sein. Retrieved June 19, 2020, from https://www.swissinfo.ch/ger/wirtschaft/schweizer-aussenhandel_die-deutsche-wirtschaft-kann-derschweiz-nicht-egal-sein/45185974

König. (2018). BIM Bauantrag. Ruhr-Universität Bochum. Retrieved June 27, 2020, from Ruhr-Universität Bochum: https://bimbauantrag.de

Kuckertz, Brändle, Gaudig, Hinderer, Morales Reyes, Prochotta, Steinbrink, \& Berger. (2020). Startups in times of crisis - A rapid response to the COVID-19 pandemic. Journal of Business Venturing Insights, 13. 10.1016/j. jbvi.2020.e00169

Latham. (1994). Constructing the Team: Final report of the Government/Industry Review of Procurement and contractual arrangements in the UK construction industry. HMSO. http://constructingexcellence.org.uk/wpcontent/uploads/2014/10/Constructing-the-team-The-Latham-Report.pdf

Lindblad \& Vass. (2015). BIM Implementation and Organisational Change: A Case Study of a Large Swedish Public Client. Procedia Economics and Finance, 21, 178-184. 10.1016/S2212-5671(15)00165-3

Loosemore. (2020). Universities need to take building education more seriously if we want to reform the industry. University of Technology Sydney. Retrieved June 21, 2020, from University of Technology Sydney: https:// www.thefifthestate.com.au/innovation/universities-need-to-take-building-education-more-seriously-if-we-wantto-reform-the-industry/

Mahlke \& Buitenhuis. (Eds.). (2019). Atlas der Globalisierung: Welt in Bewegung (2., korrigerte Auflage). Le Monde diplomatique. 
Marin. (2020). The Economic Consequences of Disrupted Global Supply Chains. World Economic Forum. Retrieved June 21, 2020, from World Economic Forum: https://www.project-syndicate.org/commentary/covid19economic-recovery-must-boost-demand-by-dalia-marin-2020-06

Mathys. (2018). Influenza-Pandemieplan Schweiz: Strategien und Massnahmen zur Vorbereitung auf eine Influenza-Pandemie. Bundesamt für Gesundheit BAG. Retrieved June 06, 2020, from Bundesamt für Gesundheit BAG: https://www.bag.admin.ch/dam/bag/de/dokumente/mt/k-und-i/hygiene-pandemiefall/influenzapandemieplan-ch.pdf.download.pdf/bag-pandemieplan-influenza-ch.pdf

McNutt, M. (2020). Lessons from the crucible of crisis. Science, 368(6492), 683. https://doi.org/10.1126/ science.abc6866

Metzger. (2020). Lasst wachsen!: Von wegen bodenständig. Die Landwirtschaft schickt sich an, zum Vorreiter für Digitalisierung zu werden. Retrieved June 07, 2020, from https://www.brandeins.de/magazine/brand-einsthema/it-dienstleister-2020/lasst-wachsen

Missiroli. (2020). Standardization, a major player in the implementation of the European Green Deal. CEN CENELEC. Retrieved July 06, 2020, from CEN CENELEC: https://www.cencenelec.eu/News/Brief_News/ Pages/TN-2020-030.aspx

Munir, Jones, \& Finnegan. (2020). BIM-based operational information requirements for asset owners. Architectural Engineering and Design Management, 23(17), 1-15. 10.1080/17452007.2019.1706439

Naturschutzring, D. (2020). Die EU zukunftsfähig machen: Forderungen der deutschen Umweltverbände an die Ratspräsidentschaft [Press release]. Berlin. https://www.germanwatch.org/sites/germanwatch.org/files/ Forderungspapier_EU-Ratspraesidentschaft.pdf

Nicał \& Wodyński (2016). Enhancing Facility Management through BIM 6D. Procedia Engineering, 164, 299-306. 10.1016/j.proeng.2016.11.623

Nývlt \& Novotný (2019). Critical factors affecting a successful BIM integrated design solution. MATEC Web of Conferences, 279, 1004. 10.1051/matecconf/201927901004

Obermaier. (Ed.). (2019). Handbuch Industrie 4.0 und Digitale Transformation: Betriebswirtschaftliche technische und rechtliche Herausforderungen. Springer Gabler.

OECD. (Ed.). (2020). Coronavirus: The world economy at risk: OECD Interim Economic Assessment. https:// www.oecd-ilibrary.org/docserver/7969896b-en.pdf?expires $=1593012784 \&$ id=id\&accname=guest\&checksum $=863 \mathrm{FD} 74 \mathrm{C} 2 \mathrm{ED} 46 \mathrm{E} 5 \mathrm{~A} 5 \mathrm{~B} 447 \mathrm{ED} 201 \mathrm{C} 39 \mathrm{~F} 16$

Olsson, J., Eriksson, L., Bengtsson, A., \& Roos, N. (2019). Unbroken digital data flow in the Built Environment - a case study in Sweden. ISPRS - International Archives of the Photogrammetry, Remote Sensing and Spatial Information Sciences, XLII-2/W13, 1347-1352. 10.5194/isprs-archives-XLII-2-W13-1347-2019

Otto \& Ditzen. (2019). Konjunkturprogramme in der Bauindustrie: Grundlagen - Durchführung - Auswirkungen. Springer Vieweg.

Parada. (2020). Understanding the sector impact of COVID-19: Engineering \& Construction. Retrieved June 17, 2020, from https://www2.deloitte.com/content/dam/Deloitte/global/Documents/About-Deloitte/COVID-19/ gx-impact-engineering-construction-sector.pdf

Pearce. (2018). Minimizing the High Risk of Failure of Corporate Innovation. ISACA Journal(2), 1-5. https:// www.isaca.org/-/media/files/isacadp/project/isaca/articles/journal/2018/volume-2/minimizing-the-high-risk-offailure-of-corporate-innovation_joa_eng_0318.pdf

Pousttchi. (2020). Digitale Transformation [Enzyklopädie der Wirtschaftsinformatik]. Lehrstuhl für Wirtschaftsinformatik. Retrieved June 27, 2020, from Lehrstuhl für Wirtschaftsinformatik: https://www. enzyklopaedie-der-wirtschaftsinformatik.de/lexikon/technologien-methoden/Informatik--Grundlagen/ digitalisierung/digitale-transformation

Price. (2020, March 24). Materials suppliers shut down amid coronavirus confusion. ConstructionNews. https:// www.constructionnews.co.uk/news/material-suppliers-shut-down-amid-coronavirus-confusion-24-03-2020/ 
Püstow, Göhlert, \& Meiners. (2018, September 20). Einbindung des Baus in die Planung: Gutachten zur Vereinbarkeit mit Haushalts- und Vergaberecht. Retrieved June 20, 2020, from https://www.bauindustrie.de/ media/documents/2018-09-20_Gutachten_Einbindung_des_Baus_in_die_Planung_final.pdf

Rau \& Oberhuber. (2018). Material Matters: Wie wir es schaffen, die Ressourcenverschwendung zu beenden, die Wirtschaft zu motivieren, bessere Produkte zu erzeugen und wie Unternehmen, Verbraucher und die Umwelt davon profitieren (I. Wilhelm, Trans.). Econ.

Ribeirinho, Mischke, Strube, Sjödin, Blanco, Palter, Biörck, Rockhill, \& Andersson. (2020). The next normal in construction: How disruption is reshaping the world's largest ecosystem. Retrieved June 06, 2020, from https:// www.mckinsey.com/industries/capital-projects-and-infrastructure/our-insights/the-next-normal-in-constructionhow-disruption-is-reshaping-the-worlds-largest-ecosystem

Rickers \& Ammermann. (Eds.). (2016). Lake Constance 5D-Conference 2016. Academic Press.

Rodeck, S.-W., \& Fischer, H. (2019). Gebaut auf Daten - digitale Immobilienwirtschaft: Vierte Digitalisierungsstudie von ZIA und EY Real Estate. https://www.zia-deutschland.de/fileadmin/Redaktion/ Positionen/zia_ey_digitalisierungsstudie_2019.pdf

Sacks, Ghang, \& Teicholz. (2018). Bim Handbook: A Guide to Building Information Modeling for Owners, Designers, Engineers, Contractors, and Facility Managers (3. Auflage). John Wiley \& Sons.

Schläper. (2020). Corona und die Schweizer Wirtschaft 2020: Online Dashboard. WüestPartner. Retrieved January 14, 2021, from WüestPartner: https://wp-corona.dataview.ch

Schmidt-Gayk. (2003). Bauen in Deutschland mit dem New Engineering Contract [Dissertation]. Universität Hannover, Hannover. https://www.repo.uni-hannover.de/bitstream/handle/123456789/6312/374004161. pdf? sequence $=1$ \&isAllowed $=\mathrm{y}$

SDA. (2020, June 23). Massiver Einbruch bei Stellenausschreibungen wegen Coronavirus: Agenturmeldung der Schweizerischen Depeschen Agentur sda. Baublatt. https://www.baublatt.ch/corona-virus/massiver-einbruchbei-stellenausschreibungen-wegen-coronavirus

Silva, F. J. (2013). Managing the unpredictable: The Black Swans in Project Management. Retrieved January 15, 2021, from https://www.winning-consulting.com/managing-the-unpredictable-the-black-swans-in-projectmanagement/?lang=en

Taleb \& Spitznagel. (2020). Die Corona-Pandemie ist kein schwarzer Schwan: Warum 2020 nach Nassim Taleb nicht mit 2008 zu vergleichen ist. Retrieved June 19, 2020, from https://www.nzz.ch/feuilleton/kein-schwarzerschwan-nassim-taleb-ueber-die-corona-pandemie-ld.1548877?reduced=false

Taleb. (2007). The black swan: The impact of the highly improbable. Random House.

Teicholz, P. (2001). U.S. Construction Labor Productivity Trends, 1970-1998. Journal of Construction Engineering and Management, 127(5), 427. https://doi.org/10.1061/(ASCE)0733-9364(2001)127:5(427)

Teicholz, P. (Ed.). (2013). BIM for facility managers. Wiley.

Tencer. (2015). Why your company is failing to innovate. Retrieved July 06, 2020, from https://www. theglobeandmail.com/report-on-business/small-business/sb-growth/why-your-company-is-failing-to-innovate/ article27510973/

Thanthirige. (2020). Cost Saving Benefits Derived through the Utilisation of Building Information Modeling (BIM) in the Design and Construction Process: Year of publication unknown, upload in 2020. School of Higher Education SHEL, San Fernando, Trinidad and Tobago. https://www.academia.edu/25202852/Cost_Saving Benefits_Derived_through_the_Utilisation_of_Building_Information_Modeling_BIM_in_the_Design_and_ Construction_Process_D31MI_Construction_Practice_and_IT

Tucci, Gautschi, \& Viscusi. (2016). Switzerland's digital future: Facts, challenges and recommendations. Retrieved June 21, 2020, from https://www.swisscom.ch/content/dam/swisscom/en/about/sustainability/digitalswitzerland/documents/epfl-study.pdf.res/epfl-study.pdf

Uhlig. (2020). Die Corona-Krise ist definitiv kein "Black Swan". Retrieved June 19, 2020, from https://www. nzz.ch/finanzen/coronavirus-die-krise-ist-definitiv-kein-black-swan-ld.1553698?reduced=false 
Vihmo \& Salo. (2020). Rakennusteollisuuden digitutkimus. Retrieved June 24, 2020, from https://www. rakennusteollisuus.fi/globalassets/ajankohtaista/ajankohtaista-liitteet/2020b/rt-digitutkimus-2020-yhteenvetotuloksista.pdf

Vozzola, Cangialosi, \& Lo Turco. (2009, September). BIM Use in the Construction Process. In 2009 International Conference on Management and Service Science (pp. 1-4). IEEE. 10.1109/ICMSS.2009.5305126

Walert \& Maniera (2020). Bauindex Schweiz Q2/2020. http://www.baumeister.ch/de/component/edocman/3725bauindex-q2-2020-de/download

WBF. (2019, February 15). Die Schweiz und Deutschland: starke Partner im Bereich Bildung, Forschung und Innovation [Press release]. https://www.wbf.admin.ch/wbf/de/home/dokumentation/nsb-news_list.msg-id-74017. html

Wildenauer. (2016a). Initial development and BIM Setup of implemented projects in Switzerland. In Lake Constance 5-D Conference. Symposium conducted at the meeting of Hochschule Konstanz, Constance.

Wildenauer. (2016b). Spielregeln für ein erfolgreiches integrales Projekt mittels BIM: CAS Studienarbeit für Fachhochschule Nordwestschweiz, Brugg. Integrales Planen (Abdruck).

Wildenauer. (2018a). Auswertung Online-Umfrage 2018: BIM in der Schweizer Immobilienwirtschaft - eine Situationsanalyse, 2. https://www.pom.ch/fileadmin/doc/Auswertung_Online-Umfrage_BIM_in_der_ Schweiz_2018.pdf

Wildenauer. (2018b). Verschenkter Datenschatz: Lebenszyklusbasiertes Datenmanagement [Life Cycle Data Management]. Build.-Ing., 2(3), 46-49. https://www.build-ing.de/fachartikel/detail/verschenkter-datenschatz/

Wildenauer. (2020a). Critical Assessment of the existing Definitions of BIM Dimensions on the Example of Switzerland. International Journal of Civil Engineering and Technology, 11(4), 134-151. http://www.iaeme. com/ijciet/issues.asp?JType $=$ IJCIET $\&$ VType $=11 \&$ IType $=4$

Wildenauer. (2020b). Evaluating 100+ use cases for BIM. buildingsmart Finland. buildingsmart Finland. InfraBIM Open 2020, Tampere, Finland. https://infrabimopen2020.exordo.com/programme/presentation/3

Winch. (2012). Managing Construction Projects (2nd ed.). Wiley. http://gbv.eblib.com/patron/FullRecord. aspx? $=698479$

Wirtz. (Ed.). (2019). Dorsch - Lexikon der Psychologie (19., überarbeitete Auflage). https://dorsch.hogrefe.com/ stichwort/ueberlebensirrtum\#search $=5 \mathrm{~d} 14495 \mathrm{cb} 03 \mathrm{a} 86 \mathrm{~d} 14 \mathrm{a} 0 \mathrm{a} 20230 \mathrm{ea66472} \&$ offset $=0$

Wolstenholme. (2009). Never waste a good crisis: A review of progress since Rethinking Construction and Thoughts of our future. http://constructingexcellence.org.uk/wp-content/uploads/2014/10/Wolstenholme_ Report_Oct_2009.pdf

WTO. (Ed.). (2020). Frequently asked questions: The WTO and COVID-19. World Trade Organization. https:// www.wto.org/english/tratop_e/covid19_e/faqcovid19_e.htm

WüestPartner. (2020). Coronavirus: Einschätzung zu den aktuellen Entwicklungen [Press release]. https:// www.wuestpartner.com/blobs/document/100735d0af5d43a33aa9820db761d2e75b05eb7f/2020_03_20_WP_ Einschaetzung_Auswirkungen_Corona-Krise.pdf

Yang \& Wei. (2010). Causes of Delay in the Planning and Design Phases for Construction Projects. Journal of Architectural Engineering, 16(2), 80-83. 10.1061/(ASCE)1076-0431(2010)16:2(80)

Zeltner. (2018). Zukünftiger Bedarf im Bereich Koordinierter Sanitätsdienst.: Gutachten von Prof. Dr. Thomas Zeltner zuhanden des Vorstehers des Eidgenössischen Departementes für Verteidigung, Bevölkerungsschutz und Sport (VBS). https://www.newsd.admin.ch/newsd/message/attachments/59943.pdf

Zeyer. (2020, May 2). Die Schweiz hat einen Pandemieplan, doch offenbar hat ihn niemand gelesen. St. Galler Tagblatt, 3. https://www.tagblatt.ch/meinung/kommentare/drum-mach-dir-einen-plan-ld.1216947

Zheng, Lu, Chen, Wing Chau, \& Niu. (2017). Benefit sharing for BIM implementation: Tackling the moral hazard dilemma in inter-firm cooperation. International Journal of Project Management, 35(3), 393-405. 10.1016/j.jproman.2017.01.006 
Adrian August Wildenauer is a Civil Engineer (Germany and Finland) and studied Construction Management in the United Kingdom, Germany and Ireland. He is currently doing his PhD at the Prague University of Business and Economics, lecturing at several Universities in Switzerland.

Josef Basl (Prof.) is Professor at the University of Economics and Business in Prague, Czech Republic. His areas of research deal with enterprise information systems and digital innovation. 